\title{
STUDI KAPASITAS TIANG BOR BERDASARKAN METODE PILE DRIVING ANALYZER (PDA) DAN LOAD CELL
}

\author{
Livia $^{1}$ dan Andryan Suhendra ${ }^{2}$ \\ ${ }^{\text {I} P r o g r a m ~ S t u d i ~ S a r j a n a ~ T e k n i k ~ S i p i l, ~ U n i v e r s i t a s ~ T a r u m a n a g a r a, ~ J l . ~ L e t j e n ~ S . ~ P a r m a n ~ N o .1 ~ J a k a r t a ~}$ \\ Email: liviaipi@gmail.com \\ ${ }^{2}$ Program Studi Sarjana Teknik Sipil, Universitas Tarumanagara, Jl. Letjen S. Parman No.1 Jakarta \\ Email: andryansuhendra@yahoo.com
}

\begin{abstract}
ABSTRAK
Pondasi tiang bor adalah pondasi yang pengerjaannya dengan cara mengebor tanah sampai kedalaman tertentu kemudian diisi dengan tulangan dan dicor beton. Pelaksanaan pondasi tiang bor harus dilaksanakan dengan cermat karena pelaksanaan berpengaruh dengan kapasitas yang dapat didukung oleh pondasi. Kapasitas dukung pondasi dapat diketahui dengan uji lapangan (Pile Driving Analyzer, Loading Test) dan/atau perhitungan manual. Penelitian ini bertujuan mengetahui perbandingan nilai kapasitas dukung tiang bor menggunakan perhitungan manual (metode Reese\&Wright, Meyerhof, Decourt, Kulhawy, Tomlinson) serta hasil tes PDA dan/atau Load Cell. Penelitian ini terdapat 6 data tanah yang berlokasi di Jakarta. Berdasarkan hasil perhitungan, diperoleh nilai rata-rata persentase perbedaan daya dukung pondasi tiang bor antara hasil perhitungan manual dengan hasil dari PDA dan load cell: metode Reese\& Wright untuk tanah kohesif dan non-kohesif sekitar 30\%, dengan metode Meyerhof untuk tanah kohesif sekitar 19\% dan untuk tanah non-kohesif sekitar 30\%, dengan metode Decourt untuk tanah kohesif dan non-kohesif sekitar 20\%, dengan metode Kulhawy untuk tanah kohesif dan non-kohesif sekitar 40\% dan dengan metode Tomlinson untuk tanah kohesif sekitar $20 \%$ sedangkan untuk tanah non-kohesif sekitar $30 \%$.
\end{abstract}

Kata Kunci: pondasi tiang bor, kapasitas dukung tiang, tes PDA, Load Cell.

\section{PENDAHULUAN}

\section{Latar Belakang}

Pondasi merupakan bagian dari struktur yang berfungsi menopang bangunan yang ada di atasnya untuk diteruskan secara merata ke lapisan tanah. Dalam merencanakan suatu pondasi, beban yang diterima oleh pondasi tidak boleh lebih besar dari pada kapasitas daya dukungnya.

Penentuan jenis pondasi harus disesuaikan dengan keadaan tanah disekitar bangunan dan besar beban yang direncanakan. Untuk beban yang besar, biasanya perencana memilih penggunaan pondasi dalam. Pondasi dalam yang umum ditemui adalah tiang bor dan tiang pancang. Pondasi bored pile dipakai apabila tanah dasarnya mempunyai daya dukung yang jauh dari permukaan tanah serta keadaan sekitar tanah bangunan sudah banyak berdiri bangunan - bangunan besar seperti gedung - gedung bertingkat sehingga dikhawatirkan dapat menimbulkan retak pada bangunan yang sudah ada akibat getaran - getaran yang ditimbulkan oleh kegiatan pemancangan apabila dipakai pondasi tiang pancang.

Ada dua metode dalam menentukan kapasitas daya dukung pada pondasi bored pile, yaitu metode statis dan dinamis. Pada umumnya, untuk menentukan daya dukung pondasi digunakan metode standard penetration test (SPT), menentukan daya dukung dari data parameter tanah dan metode loading test yang termasuk metode statis. Sedangkan untuk metode dinamis, metode pile driving analyzer (PDA) merupakan salah satu metode dinamis. Melalui studi ini, akan dianalisa perbedaan daya dukung yang dihasilkan oleh metode standard penetration test (SPT), data parameter tanah, loading test dan metode pile driving analyzer (PDA).

\section{Tujuan Penelitian}

Berdasarkan latar belakang, tujuan dari penelitian ini adalah menghitung kapasitas daya dukung pondasi bored pile dari hasil SPT, dan data parameter kuat geser tanah ; membandingkan hasil perhitungan daya dukung tiang bor dengan hasil dari pile driving analyzer dan/atau load cell ; menganalisa perhitungan kapasitas daya dukung pondasi bored pile. 


\section{Pondasi}

Pondasi adalah suatu bagian dari konstruksi bangunan yang berfungsi untuk menempatkan bangunan dan meneruskan beban yang berasal dari struktur atas. Untuk menentukan apakah suatu jenis pondasi tepat digunakan, perencana perlu mempertimbangkan beberapa hal sebagai berikut:

1. Kondisi tanah di lokasi berdirinya bangunan.

2. Besar beban yang ditimbulkan oleh struktur di atasnya.

3. Keadaan daerah di sekitar lokasi pembangunan.

4. Waktu dan biaya pekerjaan.

\section{Pondasi Bored Pile}

Ada beberapa alasan digunakannya pondasi bored pile dalam konstruksi :

1. Bored pile tunggal dapat digunakan pada tiang kelompok atau pile cap.

2. Kedalaman tiang dapat divariasikan.

3. Bored pile dapat didirikan sebelum penyelesaian tahapan selanjutnya.

4. Ketika proses pemancangan dilakukan, getaran tanah akan mengakibatkan kerusakan pada bangunan yang ada di dekatnya, tetapi dengan penggunaan pondasi bored pile hal ini dapat dicegah.

5. Pada pondasi tiang pancang, proses pemancangan pada tanah lempung akan membuat tanah bergelombang dan menyebabkan tiang pancang sebelumnya bergerak ke samping. Hal ini tidak terjadi pada konstruksi pondasi bored pile.

\section{Daya Dukung Aksial Tiang Tunggal}

Rumus daya dukung dapat diperoleh dari persamaan:

Keterangan :

$$
\begin{array}{ll}
Q_{u} & =Q_{s}+Q_{b} \\
Q_{\text {all }} & =Q_{u} / \mathrm{SF}
\end{array}
$$

$Q_{u}=$ daya dukung ultimate

$Q_{\text {all }}=$ daya dukung ijin

$Q_{s}=$ daya dukung selimut

$\mathrm{SF}=$ faktor keamanan, biasanya diambil 2,5-4.

$Q_{b}=$ daya dukung ujung

\section{Metode Reese \& Wright}

Daya dukung ujung pondasi bored pile (end bearing) berdasarkan metode Reese \& Wright dinyatakan dengan rumus :

Keterangan :

$$
Q_{\text {all }} \quad=q_{p} \times A_{p}
$$

$q_{p}=$ Tahanan ujung per satuan luas $\left(\operatorname{ton} / \mathrm{m}^{2}\right)$.

Tahanan ujung per satuan luas dapat diperoleh sebagai berikut :

a. Untuk tanah kohesif

b. Untuk tanah non-kohesif

Untuk $\mathrm{N} \leq 60$ maka,

$$
q_{p} \quad=9 c_{u}
$$

Untuk $\mathrm{N}>60$ maka,

$q_{p} \quad=7 \mathrm{~N}\left(\mathrm{t} / \mathrm{m}^{2}\right)<400\left(\mathrm{t} / \mathrm{m}^{2}\right)$

Keterangan :

$\mathrm{N}=$ Nilai rata - rata SPT

Daya dukung selimut bored pile (skin friction) berdasarkan metode Reese \& Wright dinyatakan dengan rumus :

$Q_{s}=\mathrm{f} \times \mathrm{Li} \times \mathrm{A}_{\mathrm{st}}$

Keterangan :

$\mathrm{f} \quad=$ Tahanan satuan skin friction $\left(\operatorname{ton} / \mathrm{m}^{2}\right)$.

$\mathrm{Li}=$ Panjang lapisan tanah (m).

$\mathrm{A}_{\mathrm{st}}=$ Keliling penampang bored pile $(\mathrm{m})$. 
Tahanan satuan skin friction (f) dapat diperoleh sebagai berikut :

a. Pada tanah kohesif

Keterangan :

$$
\mathrm{f} \quad=\alpha \times c_{u}
$$

$\alpha=$ Faktor adhesi.

Berdasarkan penelitian Reese \& Wright (1977) $\alpha=0,55$

$c_{u}=$ Kohesi tanah (ton $/ \mathrm{m} 2$ ).

b. Pada tanah non kohesif

Untuk $\mathrm{N}<53$ maka,

$\mathrm{f} \quad=0,32 \mathrm{~N}\left(\right.$ ton $\left./ \mathrm{m}^{2}\right)$

Untuk $53<\mathrm{N} \leq 100$ maka,

$\mathrm{f} \quad=\left(\frac{N-53}{450}\right) \times\left(\frac{1}{0,3048^{2}}\right)$

Keterangan:

$\mathrm{N}=$ Nilai N-SPT rata rata

\section{Metode Meyerhof}

Daya dukung ujung pondasi (end bearing) berdasarkan data pengujian SPT dihitung dengan persamaan Meyerhof (Bowles, 1997), yaitu :

Keterangan :

$$
Q_{p} \quad=q_{P} x A_{P}
$$

$q_{P}=20 N_{b}$ untuk tanah kohesif (ton $/ \mathrm{m}^{2}$ )

$=40 N_{b}$ untuk tanah non-kohesif (ton $/ \mathrm{m}^{2}$ )

untuk tanah non kohesif $\mathrm{qp} \leq 400 \mathrm{t} / \mathrm{m}^{2}$

$N_{b}=$ Nilai rata - rata SPT pada zona 8D keatas dan 3D kebawah ujung tiang.

Daya dukung selimut (skin friction) berdasarkan data pengujian SPT dihitung dengan persamaan Meyerhof (Bowles, 1997), yaitu:

Keterangan :

$$
Q_{s} \quad=X_{m} \cdot N_{i} x A_{s t}
$$

$X_{m}=$ Untuk tiang bor nilai $X_{m}=0,5$; Nilai $X_{m} . N_{i}$ memiliki nilai maksimum, yaitu $10 \mathrm{t} / \mathrm{m}^{2}$.

$N_{i}=$ Nilai N-SPT rata rata.

\section{Metode Decourt}

Daya dukung ujung pondasi (end bearing) dapat dinyatakan dengan rumus:

$$
Q_{p} \quad=K_{b} \times N_{b} \times A_{P}
$$

Keterangan :

$K_{b}=$ Faktor korelasi menurut Decourt. (faktor korelasi dapat dilihat di Tabel 1)

$N_{b}=$ Rata - rata nilai NSPT di ujung tiang.

Tabel 1. Faktor Korelasi Menurut Decourt $\left(K_{b}\right)$ (Canadian Geotechnical Society, 2006)

\begin{tabular}{|c|c|c|}
\hline Soil Type & Displacement Piles & Non-Displacement Piles \\
\hline Sand & 325 & 165 \\
\hline Sandy silt & 205 & 115 \\
\hline Clayey silt & 165 & 100 \\
\hline Clay & 100 & 80 \\
\hline
\end{tabular}

Daya dukung selimut (skin friction) dapat dinyatakan dengan rumus sebagai berikut:

Keterangan :

$$
Q_{s} \quad=\alpha\left(2,8 N_{60}+10\right) \times A_{s t}
$$

$\alpha=1$ untuk tiang bor untuk jenis tanah apa saja.

$N_{60}=$ Rata - rata nilai NSPT sepanjang poros tiang.

\section{Metode Kulhawy}

Untuk mendapatkan daya dukung ujung (end bearing) dapat menggunakan rumus:

$$
Q_{p} \quad=q_{p} \times A_{p}
$$

Tahanan ujung per satuan luas dapat diperoleh sebagai berikut :

a. Untuk tanah kohesif

$$
q_{p} \quad=9 c_{u}
$$


b. Untuk tanah non kohesif

Keterangan :

$$
q_{p} \quad=\sigma \mathrm{V}^{\prime} \times N_{q}
$$

$c_{u}=$ Kohesi tanah (ton $\left./ \mathrm{m}^{2}\right)$.

$\sigma v^{\prime}=$ Tegangan vertikal efektif tanah $\left(\right.$ ton $\left./ \mathrm{m}^{2}\right)$.

$N_{q}=$ Faktor daya dukung.

Faktor daya dukung $\left(N_{q}\right)$ dapat dilihat di Tabel 2.

Tabel 2. Faktor Daya Dukung (Das, 2007)

\begin{tabular}{rrrrrrrr}
\hline$\phi^{\prime}$ & $\boldsymbol{N}_{\boldsymbol{c}}$ & $\boldsymbol{N}_{\boldsymbol{q}}$ & $\boldsymbol{N}_{\boldsymbol{\gamma}}$ & $\boldsymbol{\phi}^{\prime}$ & $\boldsymbol{N}_{\boldsymbol{c}}$ & $\boldsymbol{N}_{q}$ & $\boldsymbol{N}_{\boldsymbol{\gamma}}$ \\
\hline 0 & 5.14 & 1.00 & 0.00 & 26 & 22.25 & 11.85 & .12 .54 \\
1 & 5.38 & 1.09 & 0.07 & 27 & 23.94 & 13.20 & 14.47 \\
2 & 5.63 & 1.20 & 0.15 & 28 & 25.80 & 14.72 & 16.72 \\
3 & 5.90 & 1.31 & 0.24 & 29 & 27.86 & 16.44 & 19.34 \\
4 & 6.19 & 1.43 & 0.34 & 30 & 30.14 & 18.40 & 22.40 \\
5 & 6.49 & 1.57 & 0.45 & 31 & 32.67 & 20.63 & 25.99 \\
6 & 6.81 & 1.72 & 0.57 & 32 & 35.49 & 23.18 & 30.22 \\
7 & 7.16 & 1.88 & 0.71 & 33 & 38.64 & 26.09 & 35.19 \\
8 & 7.53 & 2.06 & 0.86 & 34 & 42.16 & 29.44 & 41.06 \\
9 & 7.92 & 2.25 & 1.03 & 35 & 46.12 & 33.30 & 48.03 \\
10 & 8.35 & 2.47 & 1.22 & 36 & 50.59 & 37.75 & 56.31 \\
11 & 8.80 & 2.71 & 1.44 & 37 & 55.63 & 42.92 & 66.19 \\
12 & 9.28 & 2.97 & 1.69 & 38 & 61.35 & 48.93 & 78.03 \\
13 & 9.81 & 3.26 & 1.97 & 39 & 67.87 & 55.96 & 92.25 \\
14 & 10.37 & 3.59 & 2.29 & 40 & 75.31 & 64.20 & 109.41 \\
15 & 10.98 & 3.94 & 2.65 & 41 & 83.86 & 73.90 & 130.22 \\
16 & 11.63 & 4.34 & 3.06 & 42 & 93.71 & 85.38 & 155.55 \\
17 & 12.34 & 4.77 & 3.53 & 43 & 105.11 & 99.02 & 186.54 \\
18 & 13.10 & 5.26 & 4.07 & 44 & 118.37 & 115.31 & 224.64 \\
19 & 13.93 & 5.80 & 4.68 & 45 & 133.88 & 134.88 & 271.76 \\
20 & 14.83 & 6.40 & 5.39 & 46 & 152.10 & 158.51 & 330.35 \\
21 & 15.82 & 7.07 & 6.20 & 47 & 173.64 & 187.21 & 403.67 \\
22 & 16.88 & 7.82 & 7.13 & 48 & 199.26 & 222.31 & 496.01 \\
23 & 18.05 & 8.66 & 8.20 & 49 & 229.93 & 265.51 & 613.16 \\
24 & 19.32 & 9.60 & 9.44 & 50 & 266.89 & 319.07 & 762.89 \\
25 & 20.72 & 10.66 & 10.88 & & & & \\
\hline
\end{tabular}

Untuk mendapatkan daya dukung selimut (skin friction) dapat dinyatakan dengan rumus :

Keterangan :

$$
Q_{s} \quad=\mathrm{fx} \mathrm{Lix} \mathrm{A}_{\text {st }}
$$

$\mathrm{f} \quad=$ Tahanan satuan skin friction $\left(\mathrm{ton} / \mathrm{m}^{2}\right)$.

Tahanan satuan skin friction (f) dapat diperoleh sebagai berikut :

a. Pada tanah kohesif

$$
\mathrm{f} \quad=\alpha \times c_{u}
$$

b. Pada tanah non kohesif

$$
\mathrm{f} \quad=K_{0} \mathrm{x} \sigma \mathrm{v}^{\prime} \mathrm{x} \tan \phi
$$

Keterangan:
$K_{0}=1-\sin \phi$
$\sigma \mathrm{v}^{\prime}=$ Tegangan vertical efektif tanah $\left(\operatorname{ton} / \mathrm{m}^{2}\right)$.
$\alpha=$ Faktor adhesi.
$c_{u}=$ Kohesi tanah $\left(\operatorname{ton} / \mathrm{m}^{2}\right)$.

Kulhawy menyatakan bahwa faktor adhsesi pada tanah kohesif tergantung pada kuat geser tanah (Gambar 1).

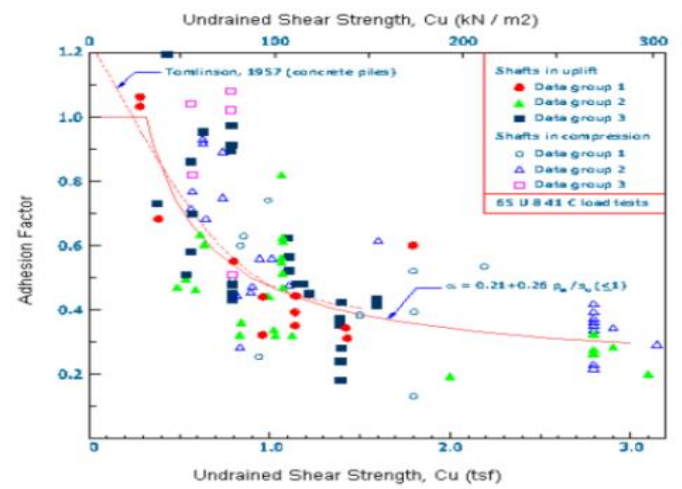

Gambar 1. Faktor Adhesi Menurut Kulhawy

(Sumber: Kulhawy, 1991) 


\section{Metode Tomlinson}

Menurut Tomlinson, perhitungan daya dukung ujung pondasi (end bearing) dapat dinyatakan dengan rumus berikut:

1. Pada tanah kohesif

$Q_{p}=A_{p} \times C_{u} \times N_{c}$

$$
Q_{p} \quad=A_{p} \times C_{u} \times N_{c}
$$

2. Pada tanah non kohesif

$$
Q_{p} \quad=A_{p} \times \sigma v^{\prime} \times N_{q}
$$

Keterangan :

$C_{u}=$ Kohesi tanah yang terdapat pada ujung tiang bor.

$\sigma \mathrm{v}^{\prime}=$ Tegangan vertikal efektif tanah $\left(\operatorname{ton} / \mathrm{m}^{2}\right)$.

$N_{q}=$ Faktor daya dukung (Nilai $N_{q}$ bisa diperoleh

$N_{c}=$ Faktor daya dukung di bawah ujung tiang bor; dari Tabel 2)

Nilai $N_{c}$ dapat diambil sebesar 9 .

Untuk perhitungan daya dukung selimut (skin friction) dapat dinyatakan dengan rumus berikut:

$$
Q_{S} \quad=\mathrm{fx} \mathrm{Lix} \mathrm{A}_{\mathrm{st}}
$$

Nilai tahanan satuan skin friction antara tanah kohesif dan non kohesif berbeda, dapat dinyatakan dengan rumus sebagai berikut:

a. Pada tanah kohesif

$$
\mathrm{f} \quad=\alpha \times c_{u}
$$

b. Pada tanah non kohesif

Keterangan:

$K_{0}=1-\sin \phi$

$\sigma v^{\prime}=$ Tegangan vertical efektif tanah $\left(\operatorname{ton} / \mathrm{m}^{2}\right)$.

$$
\mathrm{f} \quad=K_{0} \mathrm{x} \sigma \mathrm{v}^{\prime} \mathrm{x} \tan \phi
$$

Faktor adhesi menurut Tomlinson dapat diperoleh dari Gambar 2 sebagai berikut:

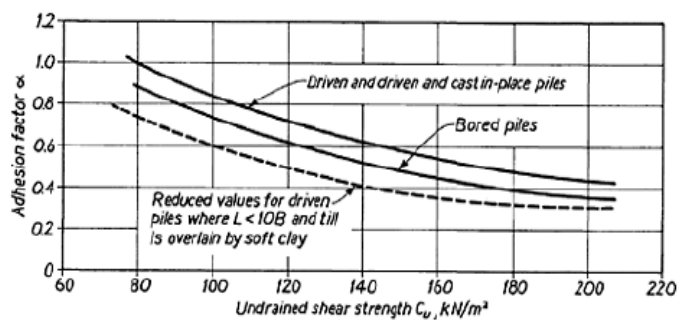

Gambar 2. Faktor Adhesi Menurut Tomlinson

(Sumber: Tomlinson, 1994)

\section{Load Cell}

Load cell adalah suatu rangkaian alat ukur elektronik yang terdiri dari sejumlah komponen yang secara bersamasama digunakan untuk melakukan suatu pengukuran dan mencatat hasilnya.

Tujuan digunakan alat load cell dalam loading test adalah untuk mendapatkan besar gaya yang diterima oleh tiang dengan lebih teliti dan mendapatkan suatu perbandingan antara besar gaya yang diterima tiang melalui hydraulic jack dan alat load cell.

\section{Pile Driving Analyzer}

Pile driving analyzer (PDA) adalah alat uji untuk mengevaluasi daya dukung tiang pondasi, baik berupa tiang pancang maupun tiang bor.

PDA merekam regangan dan percepatan gelombang yang terjadi akibat tumbukan dari palu yang dijatuhkan diatas kepala tiang dari ketinggian tertentu. Daya dukung tiang dari hasil PDA akan dianalisa lebih lanjut dengan menggunakan program CAPWAP (Case Pile Wave Analysis Program), yaitu metoda untuk menentukan persamaan 
gelombang berdasarkan parameter tanah aktif akibat beban impact, yang dikembangkan di Case Western Reserve University. Pile driving analyzer (PDA) atau uji beban dinamis memiliki beberapa keuntungan antara lain (Mhaiskar, SY. Dkk, 2010 dan Vaidya, Ravikiran dkk, 2006) :

1. Dalam satu hari dapat dilakukan test beberapa tiang sehingga menghemat waktu.

2. PDA membutuhkan ruang relative kecil.

3. PDA dapat mengevaluasi daya dukung dan integritas structural tiang.

4. PDA dapat mengevaluasi penurunan (settlement) tiang.

\section{METODOLOGI PENELITIAN}

\section{Metode Pengumpulan Data}

Metode yang digunakan untuk pengumpulan data penelitian ini adalah teknik dokumentasi dokumentasi yaitu pengumpulan data dari dari berbagai proyek. Data data yang berhubungan dengan topik yang dibahas kemudian dikumpulkan dan dilakukan perhitungan secara manual untuk mencari daya dukung pondasi tiang bor. Setelah mencari daya dukung pondasi tiang bor akan dilakukan perbandingan dengan daya dukung yang dihasilkan dari hasil uji PDA dan load cell.

\section{Metode Analisis Data}

Metode analisis yang digunakan untuk menganalisa data menggunakan microsoft excel untuk mengolah data. Sebelum dilakukannya analisis data, perlu adanya studi literature dengan mencari dasar - dasar teori dan sumber data seperti journal, buku referensi untuk mendapatkan rumus - rumus untuk mendapatkan daya dukung pondasi tiang bor.

\section{ANALISIS DAN PEMBAHASAN}

Hasil Perhitungan, Perbandingan dan Analisa Perhitungan Teoritis dengan Pengukuran di Lapangan

\section{Data Tanah Roxy Mas Business Center}

Hasil perhitungan dan perbandingan daya dukung di Proyek Roxy Mas Business Center dapat dilihat pada Tabel 3.

Tabel 3. Hasil Perhitungan dan Perbandingan Daya Dukung di Proyek Roxy Mas Business Center

\begin{tabular}{|c|c|c|c|}
\hline Metode & Daya Dukung Ujung (ton) & Daya Dukung Selimut (ton) & $\begin{array}{c}\text { Daya Dukung } \\
\text { Total (ton) }\end{array}$ \\
\hline PDA (P-7) & 36,5 & 176,5 & 212,9 \\
\hline PDA (P-20) & 50,1 & 187,4 & 237,5 \\
\hline Reese \& Wright & 23,866 & 85,690 & 109,559 \\
\hline Meyerhof & 86,429 & 93,150 & 179,578 \\
\hline Decourt & 43,214 & 115,86 & 159,072 \\
\hline Kulhawy & 23,866 & 107,8 & 131,647 \\
\hline Tomlinson & 23,866 & 149,41 & 173,275 \\
\hline
\end{tabular}

\section{Data Tanah Bintaro Icon}

Hasil perhitungan dan perbandingan daya dukung di Proyek Bintaro Icon BH-1 dan BH-2 dapat dilihat pada Tabel 4 dan Tabel 5.

Tabel 4. Hasil Perhitungan dan Perbandingan Daya Dukung di Proyek Bintaro Icon BH-1

\begin{tabular}{|c|c|}
\hline Metode & $\begin{array}{c}\text { Daya Dukung Total } \\
\text { (ton) }\end{array}$ \\
\hline Load Cell (BP-61) & 884 \\
\hline Reese \& Wright & 985,374 \\
\hline Meyerhof & 1327,378 \\
\hline Decourt & 909,452 \\
\hline Kulhawy & 687,876 \\
\hline Tomlinson & 871,393 \\
\hline
\end{tabular}


Tabel 5. Hasil Perhitungan dan Perbandingan Daya Dukung di Proyek Bintaro Icon BH-2

\begin{tabular}{|c|c|c|c|}
\hline Metode & Daya Dukung Ujung (ton) & Daya Dukung Selimut (ton) & $\begin{array}{c}\text { Daya Dukung } \\
\text { Total (ton) }\end{array}$ \\
\hline PDA (BP-09) & 214,7 & 606,1 & 820,8 \\
\hline Reese \& Wright & 113,14 & 564,166 & 677,309 \\
\hline Meyerhof & 383,163 & 598,249 & 981,565 \\
\hline Decourt & 153,33 & 496,22 & 649,547 \\
\hline Kulhawy & 113,14 & 367,205 & 480,348 \\
\hline Tomlinson & 113,14 & 525,95 & 639,090 \\
\hline
\end{tabular}

\section{Data Tanah Apartemen Emerald Bintaro}

Hasil perhitungan dan perbandingan daya dukung di Proyek Apartemen Emerald Bintaro BH-2 dan BH-3 dapat dilihat pada Tabel 6 dan Tabel 7.

Tabel 6. Hasil Perhitungan dan Perbandingan Daya Dukung di Proyek Apartemen Emerald Bintaro BH-2

\begin{tabular}{|c|c|c|c|}
\hline Metode & Daya Dukung Ujung (ton) & Daya Dukung Selimut (ton) & $\begin{array}{c}\text { Daya Dukung } \\
\text { Total (ton) }\end{array}$ \\
\hline PDA (TP I) & 116,4 & 613 & 729,4 \\
\hline Reese \& Wright & 68,96 & 354,709 & 423,669 \\
\hline Meyerhof & 201,143 & 528,971 & 730,114 \\
\hline Decourt & 162,55 & 450,97 & 613,521 \\
\hline Kulhawy & 201,143 & 250,75 & 451,893 \\
\hline Tomlinson & 265,769 & 339,9 & 605,654 \\
\hline
\end{tabular}

Tabel 7. Hasil Perhitungan dan Perbandingan Daya Dukung di Proyek Apartemen Emerald Bintaro BH-3

\begin{tabular}{|c|c|}
\hline Metode & $\begin{array}{c}\text { Daya Dukung Total } \\
\text { (ton) }\end{array}$ \\
\hline Load Cell (TP II) & 440 \\
\hline Reese \& Wright & 532,164 \\
\hline Meyerhof & 725,701 \\
\hline Decourt & 619,484 \\
\hline Kulhawy & 579,005 \\
\hline Tomlinson & 672,84 \\
\hline
\end{tabular}

\section{Data Tanah Ciputra World 2 Jakarta (Phase 3) Serviced Apartment and Condominium}

Hasil perhitungan dan perbandingan daya dukung di Proyek Ciputra World 2 Jakarta (Phase 3) tiang BP 194 dan tiang BP 205 dapat dilihat pada Tabel 8 dan Tabel 9.

Tabel 8. Hasil Perhitungan dan Perbandingan Daya Dukung di Proyek Ciputra World 2 Jakarta (Phase 3) Tiang BP 194

\begin{tabular}{|c|c|c|c|}
\hline Metode & Daya Dukung Ujung (ton) & Daya Dukung Selimut (ton) & $\begin{array}{c}\text { Daya Dukung } \\
\text { Total (ton) }\end{array}$ \\
\hline PDA & 29,9 & 1185,3 & 1215,3 \\
\hline Reese \& Wright & 102,536 & 681,877 & 784,413 \\
\hline Meyerhof & 349,643 & 795,04005 & 1144,683 \\
\hline Decourt & 139,86 & 648,741 & 788,60 \\
\hline Kulhawy & 102,536 & 483,884 & 586,419 \\
\hline Tomlinson & 102,535 & 730,74 & 833,273 \\
\hline
\end{tabular}


Tabel 9. Hasil Perhitungan dan Perbandingan Daya Dukung di Proyek Ciputra World 2 Jakarta (Phase 3) Tiang BP

\begin{tabular}{|c|c|}
\hline \multicolumn{2}{|c|}{205} \\
\hline Metode & $\begin{array}{c}\text { Daya Dukung Total } \\
\text { (ton) }\end{array}$ \\
\hline Load Cell & 1193 \\
\hline Reese \& Wright & 786,114 \\
\hline Meyerhof & 1146,8515 \\
\hline Decourt & 790,338 \\
\hline Kulhawy & 589,205 \\
\hline Tomlinson & 834,85 \\
\hline
\end{tabular}

\section{Data Tanah Gd. AJB Bumi Putera 1912, TB. Simatupang}

Hasil perhitungan dan perbandingan daya dukung di Proyek Gd. AJB Bumi Putera 1912, TB. Simatupang dapat dilihat pada Tabel 10 .

Tabel 10. Hasil Perhitungan dan Perbandingan Daya Dukung di Proyek Gd. AJB Bumi Putera 1912, TB. Simatupang

\begin{tabular}{|c|c|c|c|}
\hline Metode & Daya Dukung Ujung (ton) & Daya Dukung Selimut (ton) & $\begin{array}{c}\text { Daya Dukung } \\
\text { Total (ton) }\end{array}$ \\
\hline Load Cell (BP 39) & & & 1132 \\
\hline PDA (BP 24) & 95,8 & 1236 & 1331,8 \\
\hline Reese \& Wright & 133,33 & 773,102 & 906,398 \\
\hline Meyerhof & 557,857 & 788,078 & 1345,935 \\
\hline Decourt & 278,93 & 692,97 & 971,903 \\
\hline Kulhawy & 133,33 & 534,086 & 667,382 \\
\hline Tomlinson & 133,33 & 723,84 & 857,135 \\
\hline
\end{tabular}

\section{Data Tanah High Rise Building, SCBD}

Hasil perhitungan dan perbandingan daya dukung di Proyek High Rise Building, SCBD BH-05 dan BH-07 dapat dilihat pada Tabel 11 dan Tabel 12.

Tabel 11. Hasil Perhitungan dan Perbandingan Daya Dukung di Proyek High Rise Building, SCBD BH-05

\begin{tabular}{|c|c|c|c|}
\hline Metode & Daya Dukung Ujung (ton) & Daya Dukung Selimut (ton) & $\begin{array}{c}\text { Daya Dukung } \\
\text { Total (ton) }\end{array}$ \\
\hline PDA & 450 & 1607,7 & 2057,7 \\
\hline Reese \& Wright & 236,75 & 2509,157 & 2745,909 \\
\hline Meyerhof & 521,211 & 2480,996 & 3002,208 \\
\hline Decourt & 208,48 & 2270,1 & 2478,544 \\
\hline Kulhawy & 236,75 & 1326,297 & 1563,049 \\
\hline Tomlinson & 236,75 & 1866 & 2102,72 \\
\hline
\end{tabular}

Tabel 12. Hasil Perhitungan dan Perbandingan Daya Dukung di Proyek High Rise Building, SCBD BH-07

\begin{tabular}{|c|c|}
\hline Metode & $\begin{array}{c}\text { Daya Dukung Total } \\
\text { (ton) }\end{array}$ \\
\hline Load Cell & 2410 \\
\hline Reese \& Wright & 1743,396 \\
\hline Meyerhof & 2577,866 \\
\hline Decourt & 1864,866 \\
\hline Kulhawy & 1023,215 \\
\hline Tomlinson & 1625,593 \\
\hline
\end{tabular}

Berdasarkan data tanah yang didapat, tanah kohesif terdiri dari proyek Roxy Mas Business Center, proyek Bintaro Icon, proyek Ciputra World 2 Jakarta (Phase 3), proyek Gd. AJB Bumi Putera 1912 - TB. Simatupang, dan proyek High Rise Building - SCBD. Dan untuk tanah non-kohesif terdapat proyek Apartemen Emerald Bintaro. 
Dari hasil perhitungan dan perbandingannya, dapat dihitung persentase perbedaan daya dukung antara berbagai metode perhitungan manual dengan load cell dan/atau pile driving analyzer.

Tabel 13. Nilai Rata-rata Persentase Perbedaan Daya Dukung Antara Perhitungan Manual dengan Hasil Daya Dukung dari PDA

\begin{tabular}{|c|c|c|}
\hline Jetode & $\begin{array}{c}\text { Tanah } \\
\text { Kohesif }\end{array}$ & $\begin{array}{c}\text { Tanah } \\
\text { Non- } \\
\text { Kohesif }\end{array}$ \\
\hline Reese \& Wright & $36,789 \%$ & $41,915 \%$ \\
\hline Meyerhof & $18,733 \%$ & $0,098 \%$ \\
\hline Decourt & $26,959 \%$ & $15,887 \%$ \\
\hline Kulhawy & $41,648 \%$ & $38,046 \%$ \\
\hline Tomlinson & $22,843 \%$ & $16,965 \%$ \\
\hline
\end{tabular}

Tabel 14. Nilai Rata-rata Persentase Perbedaan Daya Dukung Antara Perhitungan Manual dengan Hasil Daya Dukung dari Load Cell

\begin{tabular}{|c|c|c|}
\hline Jetode & $\begin{array}{c}\text { Tanah Tanah } \\
\text { Kohesif }\end{array}$ & $\begin{array}{c}\text { Tanah } \\
\text { Non- } \\
\text { Kohesif }\end{array}$ \\
\hline Reese \& Wright & $23,291 \%$ & $20,946 \%$ \\
\hline Meyerhof & $19,972 \%$ & $64,932 \%$ \\
\hline Decourt & $18,348 \%$ & $40,792 \%$ \\
\hline Kulhawy & $42,846 \%$ & $31,592 \%$ \\
\hline Tomlinson & $22,069 \%$ & $52,917 \%$ \\
\hline
\end{tabular}

Tabel 15. Nilai Rata-rata Persentase Perbedaan Daya Dukung Antara Perhitungan Manual dengan Hasil Daya Dukung dari Load Cell dan PDA

\begin{tabular}{|c|c|c|}
\hline Jenis Tanah & $\begin{array}{c}\text { Tanah } \\
\text { Kohesif }\end{array}$ & $\begin{array}{c}\text { Tanah } \\
\text { Non- } \\
\text { Kohesif }\end{array}$ \\
\hline Reese \& Wright & $31,39 \%$ & $31,431 \%$ \\
\hline Meyerhof & $19,229 \%$ & $32,515 \%$ \\
\hline Decourt & $23,515 \%$ & $28,339 \%$ \\
\hline Kulhawy & $42,127 \%$ & $34,819 \%$ \\
\hline Tomlinson & $22,533 \%$ & $34,941 \%$ \\
\hline
\end{tabular}

\section{KESIMPULAN}

Adapun kesimpulan dari hasil analisis dalam penelitian ini yaitu:

1. Berdasarkan perhitungan yang telah dilakukan terdapat perbedaan antara hasil daya dukung dari perhitungan manual dengan hasil daya dukung dari PDA dan/atau load cell.

2. Nilai rata-rata persentase perbedaan daya dukung pondasi tiang bor antara perhitungan manual dengan hasil dari PDA untuk tanah kohesif dan non-kohesif paling besar menggunakan metode Reese \& Wright yaitu sekitar 36\% dan 41\%sedangkan yang paling kecil menggunakan metode Meyerhof yaitu sekitar $18 \%$ dan $0,09 \%$.

3. Nilai rata-rata persentase perbedaan daya dukung pondasi tiang bor antara perhitungan manual dengan hasil dari load cell untuk tanah kohesif paling besar menggunakan metode Kulhawy yaitu sekitar $42 \%$ dan paling kecil menggunakan metode Decourt yaitu sekitar 18\%. Sedangkan untuk tanah non-kohesif paling besar 
menggunakan metode Meyerhof yaitu sekitar 64\% dan paling kecil menggunakan Reese \& Wright yaitu sekitar $20 \%$.

4. Nilai rata-rata persentase perbedaan daya dukung pondasi tiang bor secara keseluruhan untuk tanah kohesif dan non-kohesif paling besar menggunakan metode Kulhawy yaitu sekitar $42 \%$ dan $34 \%$ sedangkan yang paling kecil untuk tanah kohesif menggunakan metode Meyerhof yaitu sekitar 19\%, untuk tanah non-kohesif menggunakan metode Decourt yaitu sekitar $28 \%$.

5. Perbedaan hasil daya dukung pondasi tiang bor dapat disebabkan oleh beberapa faktor baik faktor dari lapangan maupun faktor secara teori.

\section{DAFTAR PUSTAKA}

Bowles, J.E. (1997). Foundation Analysis and Design fifth edition. Mc Graw Hill.

Canadian Geotechnical. (2006). Canadian Foundation Engineering Manual, $4^{\text {th }}$ edition.

Das,B.M. (2007). Principles of Foundation Engineering, $6^{\text {th }}$ edition. PWS Kent.

Kulhawy, F.H. (1991). Drilled Shaft Foundation, Chapter 14 in Foundation Engineering Handbook, $2^{\text {nd }}$ Edition. New York: Van Nostrand Reinhold.

Reese, L.C. \& Wright, S.J. (1977). Drilled Shaft Design and Construction Guidelines Manual, Vol.1. Washington D.C: U.S. Departement of Transportation.

Tomlinson, M.J. and Woodward, J. (1994). Pile Design and Construction Practice fourth edition. Taylor \& Francis, Inc. 